http:/ /dx.doi.org/10.1590/0104-07072017001180015

\title{
JOB ROTATION OF NURSING PROFESSIONALS AMONG THE SECTORS OF A HOSPITAL: A MANAGEMENT TOOL IN CONFLICT RESOLUTION
}

\author{
Evelin Daiane Gabriel Pinhatti ${ }^{1}$, Marli Terezinha Oliveira Vannuchi², Denise \\ da Silva Scaneiro Sardinha ${ }^{3}$, Maria do Carmo Lourenço Haddad ${ }^{4}$
}

\footnotetext{
${ }^{1}$ Nurse. Specialist in Nursing Services Management. Londrina, Paraná, Brazil. E-mail: evelin.gabriel@sercomtel.com.br

${ }^{2}$ PhD.in Public Health. Professor, Nursing Department Professor of the Universidade Estadual de Londrina (UEL). Londrina, Paraná, Brazil. E-mail: marlivannuchi@gmail.com

${ }^{3}$ Master's student in Public Policy at the Universidade Estadual de Maringá. Nursing Coordinator of the Dr. Anísio Figueiredo Hospital. Londrina, Paraná, Brazil. E-mail: denisesardinha@uol.com.br.

${ }^{4}$ PhD in Nursing.Professor, Nursing Department, the UEL. Londrina, Paraná, Brazil. E-mail: carmohaddad@gmail.com
}

\begin{abstract}
Objective: to reveal the feelings and perceptions of nursing professionals who underwent the process of job rotation among sectors of a hospital as a management tool in conflict resolution.

Method: a qualitative study carried out with 22 professionals, nurses and nursing technicians, using the focus group technique and content analysis based on the theoretical reference of Symbolic Interaction.

Results: the job rotation process was positive regarding factors that help in resolving conflicts such as: increased knowledge and skills, recognition of the activities performed by peers, and improved interpersonal relationships, in addition to reducing resistance when working in other sectors. However, this process elicited anxiety, fear, frustration, sadness, distress, and insecure feelings attributed to ineffective communication and to the lack of the team's participation in developing the proposal.

Conclusion: job rotation is an important strategy for reducing conflict; however, it is essential that managers share this proposal with the team before implementing it.
\end{abstract}

DESCRIPTORS: Human resource management. Conflict (Psychology). Nursing staff. Group processes. Reorganization of human resources.

\section{RODÍZIO DE PROFISSIONAIS DE ENFERMAGEM ENTRE SETORES DE UM HOSPITAL: FERRAMENTA GERENCIAL NA RESOLUÇÃO DE CONFLITOS}

\section{RESUMO}

Objetivo: desvelar sentimentos e percepções de profissionais de enfermagem submetidos ao processo de rodízio entre setores de um hospital como ferramenta gerencial na resolução de conflitos.

Método: estudo qualitativo, realizado com 22 profissionais enfermeiros e técnicos de enfermagem, utilizando-se grupo focal e análise de conteúdo, com base no referencial teórico do Interacionismo Simbólico.

Resultados: o rodízio foi positivo para fatores que auxiliam a resolução de conflitos: aumento de conhecimentos e habilidades, reconhecimento das atividades desempenhadas pelos pares, melhora no relacionamento interpessoal, além de reduzir a resistência ao se atuar em outros setores. Contudo, suscitou sentimentos de ansiedade, medo, frustração, tristeza, angústia e insegurança atribuídos à comunicação ineficaz e à falta de participação da equipe na elaboração da proposta.

Conclusão: o rodízio é uma estratégia importante para a redução de conflitos, todavia é fundamental que os gestores compartilhem essa proposta com a equipe antes de implementá-la.

DESCRITORES: Administração de recursos humanos. Conflito (Psicologia). Equipe de enfermagem. Processos grupais. Reorganização de recursos humanos. 


\title{
ROTACIÓN DE PROFESIONALES DE ENFERMERÍA ENTRE SECTORES DE UN HOSPITAL: INSTRUMENTO DE GESTIÓN EN LA RESOLUCIÓN DE CONFLICTOS
}

\begin{abstract}
RESUMEN
Objetivo: desvelar los sentimientos y percepciones de profesionales de enfermería sometidos al proceso de rotación entre sectores de un hospital como instrumento de gestión en la resolución de conflictos.

Metodo: estudio cualitativo se ellevó a cabo con 22 profesionales, enfermeros y técnicos de enfermería, utilizando la técnica de grupo focal y análisis de contenido, con base en el referencial teórico del interaccionismo simbólico.

Resultados: el proceso de rotación fue positivo para factores que auxilian en la resolución de conflictos como: aumento de conocimientos y habilidades, reconocimiento de las actividades desarrolladas por sus pares, mejora en el relacionamiento interpersonal, además de reducir resistencia al actuar en otros sectores. No obstante, suscitó sentimientos de ansiedad, miedo, frustración, tristeza, angustia e inseguridad, atribuidos a la comunicación ineficaz y a la falta de participación del equipo en la elaboración de la propuesta.

Conclusión: la rotación es una estrategia importante para la reducción de conflictos, sin embargo, es fundamental que los gestores compartan esa propuesta con el grupo antes de implementarla.

DESCRIPTORES: Administración de recursos humanos. Conflicto (psicología). Equipo de enfermería. Procesos grupales. Reorganización de recursos humanos.
\end{abstract}

\section{INTRODUCTION}

Group activities are part of the everyday life of several professions, although often performed mechanically. Groups can contribute to professional success or failure according to the context experienced in organizations, related to structural aspects, functioning dynamics and interpersonal relations. ${ }^{1}$

The diversities that exist in groups are inevitable, and it is the inability to deal with these differences that generate conflicts which can directly influence work outcomes. ${ }^{2}$ Conflicting situations generate feelings of frustration due to the impossibility of understanding the interests and needs of the subjects involved, and interpreting the facts from an individual point of view. ${ }^{3}$ The most common sources of conflict in institutions are problems in communication, organizational structure, and individual behavior. ${ }^{4}$

Nursing is a profession characterized by group work, so the way in which social relationships are established in the organizational environment can influence the dynamics of interactions and contribute to both pleasure and suffering of group members. Group cohesion improves work team functioning, generating greater professional satisfaction and lower rates of Burnout syndromes. ${ }^{5}$

Nursing team conflict situations when well conducted contribute to the professional and personal development of those involved, generating greater worker satisfaction, impacting on the quality of the care process. In this context, the literature ${ }^{6}$ reports that successful teams present clear and candid communication, acknowled ge conflicts, and seek to resolve them in a positive way.
A study carried out with nursing workers revealed that the psychic burnout resulting from the very nature of the work of carrying for sick individuals is less impacting on their quality of life than the emotional stress caused by the situations and interpersonal relations present in the work environment. $^{7}$

In this sense, considering that interpersonal relationships can generate emotional exhaustion for professionals, some institutions have used job rotation among the sectors as a means to increase the knowledge levels of their employees, thus promoting work qualification; and this strategy can improve social skills and the relationships between working groups. ${ }^{8-11}$ The rotation process or employee rotation is a managerial tool derived from the Toyota Production System in the 1950s, with the objective of enabling the worker to work in different jobs. ${ }^{9}$

The expression "job rotation" was created from this production system, which (as its name indicates) emerges as a tool to temporarily alternate worker activities in order to 'flexibilize' and qualify the workforce. ${ }^{8}$

This practice consists of a systematized rotation with previously defined objectives and scheduling among those involved in the process. In nursing, this tool should be used as a part of career development and career guidance program, aiming at increasing the level of quality at work. ${ }^{8}$

Therefore, understanding the perceptions of nursing workers regarding the use of the rotation strategy between sectors allows managers to evaluate the effectiveness of the action as a managerial tool for developing teams, for resolving conflicts and for increasing professional satisfaction, aspects that can affect the quality of the care process. 
The theoretical reference of Symbolic Interactionism was used to understand the experiences of the rotation process. This theory focuses on the nature of interaction and social dynamics among people, above all valuing the meaning that human beings attribute to their experiences. ${ }^{12-13}$

In Symbolic Interactionism, perspectives are shared, decisions are made, directions are changed, reality is defined and the role of others is assumed, all by interacting with other subjects. From this point of view, the individual recognizes themself as an active being who deals with situations and establishes their actions in accordance with their own interpretation. Thus, from the interaction, the experiences are used as a support for future actions, leading to a re-signification of the experienced situation. ${ }^{12-13}$

In this context, the objective of this study was to unveil the feelings and perceptions of professionals about the nursing rotation process among hospital sectors as a management tool for conflict resolution.

\section{METHOD}

This study consisted of an exploratory-descriptive and qualitative research, since there was the intention to relate the meaning that the participants attributed to their experiences in their work processes. The field of study was a state hospital of medium complexity in a city in the South of Brazil. This institution has 117 beds distributed across sectors of a medical clinic, surgical clinic, emergency room and pediatrics, as well as a surgical center.

At the time of this study, the nursing team was composed of 40 nurses and 130 professionals among nursing technicians and nursing assistants, working 12-hour day or night shifts followed by 36 hours of rest. The research participants corresponded to 15 nurses, 61 (nursing) technicians and nursing assistants from the daytime shift who participated in the job rotation strategy proposed by the nursing directorate of the institution for one month in the year 2013, and were from the emergency units and the medical, pediatric and surgical inpatient clinics.

The adopted inclusion criterion was aimed at the participants who experienced the rotation process of nursing professionals among the hospital sectors conducted in 2013. Those who were on vacation or on leave were excluded. In order to compose the sample, a random draw was used for nursing technicians and nursing assistants, since they were the majority, ensuring that the groups were composed of the inpatient clinic and emergency room workers. We highlight that nursing assistants were not included in the draw due to there being a reduced number of them in the studied institution. Regarding nurses, all those who were working on the day proposed for data collection and who formally accepted to participate in the research were included.

The data were collected in September 2014, using the focus group technique, which consists of an interview with the objective of capturing data through interactive communication, making it possible to explore beliefs, values, concepts, conflicts, confrontations and points of view through group interaction. ${ }^{14}$ The following guiding question was applied to start the dialogues: "How was it for you to participate in the job rotation of professionals between the emergency room and the inpatient units?" Auxiliary questions were applied in opportune situations which contributed to the quality of the testimonials.

Four focus groups were performed with two groups composed of six nursing technicians subdivided into $A$ and $B$, and two groups composed of five nurses, equally subdivided into $A$ and $B$ shifts. This division aimed to allow for the participants to have freedom to expose their perceptions of the other category. The meetings were performed during the work period and lasted an average of one hour. Regarding the number of participants in each group, we sought to follow the minimum quantitative guidance proposed in the literature ${ }^{14}$ regarding focus groups in order to not disrupt the activities of the sectors.

The speeches were recorded into audio format and later the literal transcription of the focus group dialogues and the respective records of the non-verbal communication were derived from the observer's notes, whose information supported understanding of the group discourse. Data was analyzed through the Content Analysis technique, according to the following steps: pre-analysis, material exploration and results treatment achieved through inference and interpretation. ${ }^{15}$ The transcription was done in the pre-analysis and exploration phases of the material, followed by floating data reading to identify relevant aspects from the study objective, seeking to produce registration and contextual units and identify the possibilities of building thematic/ category axes. Finally, the categories were deepened in treating the results, articulating the empirical data with the relevant theoretical material.

In order to preserve the identity of the interviewees and to differentiate them, they were all identified by alphanumeric codes, in which the acronym $\mathrm{N}$ stands for nurses and NT for nursing 
technician, followed by numbers indicative of their statement order.

The study was carried out in order to ensure compliance with the precepts of Resolution n. $466 / 2012$ on research involving human beings. ${ }^{16}$ The project was approved by the Research Ethics Committee, obtaining a favorable opinion and Presentation Certificate for Ethical Appraisal n. 34232214.1.0000.5231.

\section{RESULTS AND DISCUSSION}

From the 22 participants in the study, 19 professionals were female, aged between 26 and 54 years old. Of these, 14 had less than ten years of professional experience, and all of them had worked at the institution for four years due to the last public statutory contract.

The results obtained from the focus group speeches were grouped into thematic categories regarding the rotation process of nursing professionals between the inpatient and emergency departments, with four categories emerging: feelings experienced from the announcement of the rotation process; embracing the professionals; perceptions about the work process; and evaluation of the rotation process. Two aspects constituting the subcategories emerged from the category perceptions about the work process are denominated here as facilities and difficulties.

\section{Feelings experienced from the announcement of the rotation process}

Usually the unknown generates uncertainties that can psychologically affect individuals, considered as a natural resistance. Those less receptive to change may experience negative emotional reactions, including frustration, anxiety, insecurity, anger and fear. The testimonies revealed difficulties in dealing with the rotation process between sectors, as we can observe from the following statements:

[...] it was frustrating to leave my workplace and go to another, it affected my emotional state, my way of working, everything, it destabilized everyone (NT1).

[...] It also made me a little angry, because I did not want to do it, but I had to do it (NT4).

[...] I was sad. At first I didn't want to go, I didn't accept it at all, my feeling was of indignation, revolt (NT3).

[...] I felt insecure about being in a new sector [...] But I have no problem in learning (NT7).
[...] fear [...]. You are not used to change, you are used to the routine, to your sector? (NT9).

[...] Apprehensiveness. Fear, fear of what's new [...]. At first, we are resistant, it puts us outside the comfort zone, that routine that we are already used to (N1).

The statements emphasize different feelings by the interviewees when dealing with the new situation, which goes with the conception that resistance to change is shaped by two basic anxieties: the fear of losing stability and a fear of attack from the new situation. ${ }^{2}$ However, it is emphasized that the reasons why individuals react to organizational changes may be multifactorial, arising both from individual perceptions and from the organizational context. Components of cognitive, affective and behavioral aspects stand out among causes that generate individual resistance. Causes for resistance in this context are related to information, participation, motivation, safety at work, and trust in management, among others. ${ }^{17}$

In this sense, studies reveal that a pleasant organizational atmosphere is more relevant than individual or psychological variables when assessing openness to experiencing changes. ${ }^{17}$ However, considering individuality, it is understood that resistance to organizational change may involve not necessarily coinciding ambivalent feelings, as shown in the following excerpts: for me it was positive because I like the inpatient clinic, because it is a sector that has more routine, you can organize things better (N7); maybe I'm a little different from the others, because as I've worked in many places, I see things more naturally (N3).

Previous experiences can positively or negatively contribute to the new situation. Studies also demonstrate that the values of individuals are fundamental in the cognitive system. Thus, more idealistic people are more open-minded and consequently less resistant to change, which favors introducing new ideas and technologies for developing the institution. ${ }^{17}$ Another factor pointed out by the workers in relation to the rotation process was the inadequate instruction, as expressed by the following participants: this announcement that we were going to the rotation, for what reason? To learn routine? To get to know the team? There was none of this [...] It's like this, look, so-and-so you're going to the inpatient clinic, you're going to evaluate this and that, okay? We'd go with a different vision (N6); they don't even tell us why they're doing it or not, this ends up generating insecurity, discomfort, resistance [...] It was something that wasn't well explained (N10); the management should have talked to us, explained the decisions, the changes to the team, to reassure us (T11). 
Communication is inherent to life in groups. The way it is shared and understood can influence and modify the reality in which individuals are inserted. In this sense, we emphasize that communication based on dialogue and interaction can generate changes and new behaviors, as it allows for feelings of being integrated with the group, of identifying with it, attributing meanings to the actions developed in the work routine. ${ }^{2,18}$

Communication is not always successful in healthcare institutions, and there may be distortions in information, impairing the operationalization of the work process. Studies ${ }^{18-19}$ have revealed that centralization of the decision-making process along with vertical communicative process can also hamper good work performance. Similarly, the hierarchical communication model can cause distortions of the initial message given the complexity of the communication process and the subjectivity of the interpreter, since it is influenced by individual values and conceptions. ${ }^{18}$

Lastly, it should be stressed that effective communication is essential for transferring information in labor relations, making it possible to carry out coordinated actions, minimizing differences and making it possible to reach common objectives. ${ }^{18}$

\section{Embracement of professionals}

Although group coexistence has been part of human life since ancient times, whether in the family, school, church, or among other environments, the process of inserting a new member into the group is not always clearly perceived.

[...] I had difficulty, because they had their group, the management also had more affinity with them, and they did not care about you. They even demanded a little more than the group that was there. Sometimes they would make our shift with the hardest patients (NT5).

[...] I basically felt excluded by a nurse, an issue that I saw, and she gave preference to the people who were already there (NT1).

[...] sometimes I felt somewhat afraid to ask for help [...]. Not that the person did not want to help me, but to show that I was needing help (NT4).

The statements revealed difficulties encountered regarding interpersonal relationships, considering that the participants reported a lack of affinity, fear and a feeling of exclusion. Even the nurses who are the unit's formal leaders were singled out for failing to adequately welcome the professional in the rotation process and to provide benefits to their workforce. Thus, we can consider that in the dimen- sion of nursing work, those who have the responsibility of coordinating nursing work teams often face difficulties in relation to leadership, communication and interpersonal relationships. Therefore, it is relevant to consider the importance of knowledge about group dynamics for these professionals. ${ }^{2}$

We emphasize that people are in constant interaction when in groups, and the many relationships experienced will somehow impact the singularity of each one; a fact that confirms the theory of Symbolic Interactionism. ${ }^{12-13}$ In this way, it is necessary to consider the various networks that intersect each other with their own values, beliefs, fears, affinities and defense mechanisms. ${ }^{2}$ However, it is observed that opinions differ in relation to reception into the group, and this may have occurred both due to the personality traits of those more likely to incorporate changes, as well as to the unique characteristics of the leader and the group that is receiving them.

The reception was good, they treated me well, they respected me [...]. It was good to meet the team, because until then I had not worked with any of them, it was very exciting (N8).

I was really welcomed, and that was what I was the most surprised about [...]. We stop dealing with other people with our daily routine and I got on very well with them, I felt welcomed (N3).

The perception of acceptance, approximation or detachment to which the statements refer to can be explained by the concept of group dynamics (known as tele), which is the disposition one has toward working with others. If on the one hand negative tele is considered a difficulty or refusal to work with others, on the other a positive tele consists of the possibility and the acceptance of working with others. In this sense, the rotation among sectors allowed for a manifestation of positive tele, either on the part of the individual or of the members of the group, thus favoring work development. ${ }^{2}$

\section{Perceptions about the work process: Facilities and difficulties}

Regarding facilities, respondents expressed an increase in their levels of knowledge and skills from the new experience.

I think that today I have a better handle on some things that we hardly ever saw in the inpatient clinic. You even know how to do it, but you don't have the ability. So, from this point of view I grew professionally, in terms of knowledge (NT6).

[...] more experience, more security, I grew, you know? But it was difficult, I didn't want to go, I suf- 
fered, I cried, I wanted to disappear from there at first, but then it was good, because I grew in relation to the procedures (NT3).

[...] it was a new experience, because I had never worked in the emergency room, it was all new, so the new experiences were valid (NT2).

It is evident from the statements that the method of job rotation added knowledge from the experience of a reality until then unknown, in addition to allowing a better understanding of the functionality of other sectors, and consequently of the institution. Therefore, the findings of this study agree with the literature, evidencing that the practice of rotation creates opportunities to learn new skills and expand professional knowledge by creating variety in work content, being able to alleviate the monotony resulting from the repetitive tasks of daily routine. ${ }^{8,10-11}$

Some authors also point out that strategy is an ally in reducing burnout, since in addition to changing assignments, new challenges can encourage enthusiasm, stimulate the spirit of work and cultivate interpersonal relationships. ${ }^{8,10-11}$ Relief from situations inherent to their original sector and positive perceptions of the rotation sector are evident in the statements.

I think we have to do it, because no matter how much you like the sector you are in, you get tired from the day to day (T7).

There in the inpatient clinic I'm able to learn the name of all the patients, the diagnosis, it was very good (T10).

I realized the positive aspects, so that I even wanted to take somethings to the inpatient clinic (N1).

The rotation was positive for us to get out of our comfort zone, to get to know other places, change the stale look a bit, because when you come back, you also notice in your sector: 'Wow, that crack, this light that does not switch on, which I had forgotten' (N3).

It is possible to notice satisfaction of being in another sector with different work processes in the statements. This experience of the worker can provide new perspectives and lead to implementing new attitudes and improvements both in the rotation sector and in their return to their original sector, in addition to being perceived as a relief from daily assignments. Moreover, the professionals expressed relevant perceptions after their experience in the rotation process.

Among them [the inpatient clinic team] there is a lot of companionship [...]. You need it, I need it too, I help you, you help me, there's union in the group (N2).
The fact that a person goes through the experience of being you, of doing what you do [...]. They can better understand your difficulties (N2).

The understanding about the sector, the routine, because we have an idea, but when you are part of it, you are there experiencing the routine, your perception of things changes (N8).

According to the statements, it was possible to verify that the job rotation is capable of promoting personal performance, improving the confidence to perform new tasks, and optimizing flexibility in the work community, in addition to providing professional development. Still in the personal sphere, participants may feel motivated to cultivate interpersonal relationships, and above all, it can be an important way to improve personal resilience, making work life more dynamic and flexible., ${ }^{8,10}$ This observation reaffirms the proposal of the Symbolic Interactionism theoretical reference used in this study; in the sense that their interactions and experiences can lead to a re-signification of future actions.

With regard to the difficulties encountered in the rotation sector, professionals highlighted aspects in relation to work process, as shown by the following statements: in the emergency room you have to care for every patient that comes through the door. Sometimes there are a thousand stretchers, a thousand beds, and you have to see everyone. (NT6); [...] and to change shifts? Who is this person? Where's the person that was (just) here? [...] It seems that I have no control of the situation and I can't work like this (N8); I like the inpatient clinic, because I have (more) contact with the patients, we can see their evolution. In the emergency room no, today I am with the patient, tomorrow they are no longer there, I don't know if they get better (NT9).

Emergency units are known for their dynamism in the work process. The professionals who work there are challenged by the demand that often exceeds the service capacity. Moreover, this demand must be answered with speed, requiring workers to have the ability to act under pressure, high psychomotor ability and aptitude, as they constantly have to deal with excessive numbers of patients requiring care for a variety of clinical conditions. ${ }^{20-21}$

Unpredictability is a characteristic trait of the urgency and emergency units and generates the need to be always alert, which can lead to stress overload due to emotional exhaustion as it is an unstable and agitated environment requiring rapid decision making and constant reorganization of the work process. ${ }^{22}$ However, it was possible to identify the affinity of some professionals allocated to this sector in the statements. 
In the emergency room it is different, your brain never stops, we are more alert, you are with one patient here, but keeping an eye on the other one over there, and in the inpatient clinic everything is very organized, very smooth, and I can't work like that (T11).

I really don't like the inpatient clinic, due to its characteristic of being mostly older people with chronic diseases, bedridden patients, geriatric matters [...] stuff I don't really like, I get depressed (N3).

Dynamism and the unexpected as part of the work process in the emergency room does not limit the professional to feel fulfilled in their performed activities. Another aspect that arises from this process is the difficulty of nurses in performing their activities of team management and decision making.

You take the lead or delegate something that nursing technicians know way better than you (N7).

You also end up not taking over the team too much, because you will only be there for a month [...] and you can't interfere too much in the routine, otherwise you end up not being well accepted (N9).

You start from scratch with the insertion process, you are entering into a team (N2).

In this context, the group insertion process can be resumed, which requires the individual to be willing to socialize. ${ }^{2}$ However, the job rotation tool allowed the professional to act in the units only for a short period; not enough time for them to have had the opportunity to integrate and incorporate their social identity into the group, assuming a formal leadership role that is legally established.

\section{Evaluation of the rotation process}

There are several perceptions about the rotation strategy which derive from subjective questions of the individual themself, or of the environment in which they are received. In essence, it is worth mentioning knowledge expansion, recognition of the activity performed by their peers, a reduction in resistance for acting in another sector, and improvement in interpersonal relationships.

What was good in the rotation was that each one was able to be in somebody else's place, to put themselves in someone else's shoes, in addition to acquiring knowledge. The important thing is that it was not an abrupt thing, it was gradual, taking a piece from here and putting it there (N3).

I think it has improved my vision, I didn't imagine it was so hard [the inpatient clinic], I thought I wouldn't have to ask for help for anything (NT4).

You judge things by not knowing them. Our evil is to have a preconception, thinking that it is, when it is not.
It is by experiencing the ER routine that you understand why you didn't send the patient punctually, because they hadn't collected a swab (NT5).

In this sense, considering the participants' statements we can notice that the experience in a different sector increased their knowledge of the work process in the unit of their peers, allowing them to go beyond individual goals and focus on collective goals, driven to improve organizational performance.

In the hospital context, while it seems prudent to let employees perform the same usual tasks, this does not favor the ability to adapt to new scenarios. Thus, professionals' skills and competencies will be very restricted if they are only familiar with the nursing of their units. ${ }^{8}$

Considering that organizations' and professionals' performance can be influenced by a resistance to change attitude, the results were satisfactory, despite the initial feeling brought by the rotation process.

It can be said that the break that I am from this sector and I belong to this sector was positive. To help ourselves today, the resistance in helping each other has somerwhat diminished (N10).

I think that from learning the routine of another sector, we get richer. You see the difference, we mature [...]. Today, if I need to cover the ER I go, it's not that I like it, but I'll do it (N7).

Today, if I need to go to the ER, I will, that difficulty no longer exists, because I already know it, I don't have that resistance from before (NT7).

It is observed in the statements that the participants migrated from a partial view to a holistic point of view of the institution and the peers. The literature shows that professional rotation benefits both parties: professionals are willing to acquire new skills and expand their knowledge in the profession; and it promotes flexibility in the management of human resources in the work community. 8,11

Regarding interpersonal relationships, part of the group perceived that there was improvement in their relationships, and there was also a reduced amount of conflicts.

The conflicts are less due to this vision of understanding, getting to know how the other sector works (N9).

What I thought was good was that there were people who I didn't have a friendship connection with. I didn't know other people well, and after the rotation we ended up making new friendships (NT9). 
As a positive I see the union between the (nursing) technicians, because we used to work in the same hospital and didn't even know each other, it seemed strange, we didn't even know each other's names (NT7).

In this study, closeness between team members and the opportunity to work together were important factors in reducing conflicts, which reaffirms the adopted theoretical framework.

A study which aimed to evaluate conflict situations in the hospital context evidenced the need for the work to be carried out in a team, subsidized by values of: cooperation, respect, trust, exchange of experience and union. In the same way, making the common objectives of the institution and the team clear constituted an essential aspect for reducing organizational conflicts. ${ }^{4}$ Implementing the rotation tool of employees between hospital units can help managers and employees in acquiring such skills.

\section{CONCLUSION}

The findings of this study revealed that the rotation process between hospital sectors was positive regarding factors that help resolve conflicts, such as in increasing knowledge and skills, recognizing activities performed by peers, improving interpersonal relationships, and reducing resistance to work in another sector.

However, the tool aroused diverse feelings of anxiety, anger, fear, frustration, sadness, anguish and insecurity. In this sense, it should be considered that the way individuals react to change derives both from individual perceptions and from the context. Thus, some weaknesses of the context pointed out by the nursing team may have contributed to the emergence of these feelings, namely ineffective communication and the lack of participation of the team in elaborating the strategy.

In this way, it becomes clear that managers should address some aspects for the reducing resistance before implementing strategies, aiming to increase team performance and reduce the negative feelings that accompany it. It is therefore essential to clarify the purpose and advantages of cross-sectoral rotation, to ensure that the strategy is transparent and that the nursing team has the opportunity to participate in administrating the rotation and offering suggestions for improvement, thus granting them co-responsibility for the process.

The time elapsed between the rotation and the data collection was considered as a limitation of this study, since the collection occurred in the year following the rotation, which may have interfered in the participants' perception. However, it is believed that the findings of this study may not only contribute to researchers, but also to managers in the health area, as knowing the performance of this tool allows for using and optimizing the strategy, considering the benefits for both parties. For the professional, this tool allows them to acquire new skills and expand their knowledge in their profession. It also promotes flexibility in the management of human resources in the work community.

\section{REFERENCES}

1. Munari DB, Padilha GC, Motta KAMB, Medeiros M. Contribuições para a abordagem da dimensão psicológica dos grupos. Rev Enferm UERJ [Internet]. 2007 [cited 2015 Oct 10]; 15(1): 107-12. Available from: http://www.facenf.uerj.br/v15n1/v15n1a17.pdf

2. Cardoso ASF, Dall'Agnol CM. Group process: reflections of a nursing team. Rev Esc Enferm USP. 2011; 45(6):1406-12.

3. Cianmpone MHT, Kurcgant P. Gerenciamento de conflitos e negociação. In: Kurcgant P, coordenadora. Gerenciamento em enfermagem. Rio de Janeiro (RJ): Guanabara Koogan; 2012.

4. Spagnol CA, Santiago GR, Campos BMO, Badaró MTM, Vieira JS, Silveira APO. Conflict situations experienced at hospital: the view of nursing technicians and auxiliaries. Rev Esc Enferm USP [Internet]. 2010 [cited 2015 Jan 05]; 44(3): 803-11. Available from: http://www.scielo.br/pdf/reeusp/v44n3/en_36.pdf

5. Kalisch BJ, Lee H, Rochman M. Nursing staff teamwork and job sastifaction. J Nurs Manag [Internet]. 2010 [cited 2014 Dec 12]; 18(8):938-47. Available from: http:/ / www.ncbi.nlm.nih.gov/pmc/ articles/PMC2994317/

6. Chiavenato I. Gestão de pessoas. $3^{\mathrm{a}}$ ed. Rio de Janeiro (RJ): Elsevier; 2010.

7. Mininel VA, Baptista PCP, Felli VEA. Cargas psíquicas e processos de desgaste em trabalhadores de enfermagem de hospitais universitários brasileiros. Rev Latino-am Enferm. 2011 Mar-Abr; 19(2):340-7.

8. Jarvi M, Uusitalo T. Job rotation in nursing: a study of job rotation among nursing personnel from the literature and via a questionnaire. J Nurs Manag. 2004; 12:337-47.

9. Shingo S. Study of Toyota production system from industrial engineering viewpoint. Tokyo, Japan Management Association; 1981.

10. Ho WH, Chang CS, Shih YL, Liang RD. Effects of job rotation and role stress among nurses on job satisfaction and organizational commitment. BMC Health Serv Res. 2009; 9:8-15.

11. Chen SY, Wu WC, Chang CS, Lin CT. Job rotation and internal marketing for increased job satisfaction and organizational commitment in hospital nursing staff. J Nurs Manag. 2015 Apr; 23(3):297-306. 
12. Dupas G, Oliveira I, Costa TNA. A importância do interacionismo simbólico na prática de enfermagem. Rev Esc Enferm USP. 1997 ago; 31(2): 219-26.

13. Lopes CHAF, Jorge MSB. Symbolic interacionism and the possibility to the interactive care in nursing. Rev Esc Enferm USP. 2005 Mar; 39(1):103-8.

14. Ressel LB, Beck CLC, Gualda DMR, Hoffmann IC, Silva RM, Sehnem GD. O uso do grupo focal em pesquisa qualitativa. Texto Contexto Enferm [Internet]. 2008 [cited 2014 Jun 06]; 17(4): 779-86. Available from: http://www.scielo.br/pdf/tce/v17n4/21.pdf

15. Bardin L. Análise de conteúdo. São Paulo (SP): Edições 70; 2010.

16. Ministério da Saúde (BR). Conselho Nacional de Saúde, Comissão Nacional de Ética em Pesquisa. Resolução n ${ }^{\circ} 466$ de 12 de dezembro de 2012: diretrizes e normas regulamentadoras de pesquisa envolvendo seres humanos. Brasília (DF): MS; 2012.

17. Freires DAN, Gouveia VV, Bortolotti SLV, Ribas FTT. Resistência à mudança organizacional: perspectiva valorativa e organizacional. Psico (Porto Alegre). 2014 Out-Dez; 45(4):513-23.

18. Santos JLG, Prochnow AG, Lima SBS, LeiteJL, Erdmann
AL. Communication conceptions in hospital nursing management between head nurses in a university hospital. Rev Esc Enferm. USP [Internet]. 2011 [cited 2015 Jan 14]; 45(4):959-65. Available from: http:/ /www. scielo.br/pdf/reeusp/v45n4/en_v45n4a24.pdf

19. Azambuja EP, Pires DEP, Vaz MRC, Marziale MH.É possível produzir saúde no trabalho da enfermagem? Texto Contexto Enferm. [Internet]. 2010 [cited 2015 Abr 03]; 19(4):658-66. Available from: http://www. scielo.br/pdf/tce/v19n4/08.pdf

20. Seleghim MR, Mombelli MA, Oliveira MLF, Waidman MAP, Marcon SS. Sintomas de estresse em trabalhadoras de enfermagem de uma unidade de pronto-socorro. Rev. Gaúcha Enferm [Internet]. 2012 [cited 2015 Jan 10]; 33(3):165-73. Available from: http:/ / www.scielo.br/scielo.php?pid=S198314472012000300022\&script=sci_arttext

21. Gehlen GC, Lima MADS. Nursing work in care practice at emergency care units in Porto Alegre/RS. Invest Educ Enferm. 2013; 31(1): 26-35.

22. Garcia AB, Dellaroza MSG, Haddad MCL, Pachemshy LR. Prazer no trabalho de técnicos de enfermagem do pronto-socorro de um hospital universitário público. Rev Gaúcha Enferm. 2012 Jun; 33(2):153-9. 